\title{
Experimental Study for Sand Filter Backwash Water Management: Low-Cost Treatment for Recycling and Residual Sludge Utilization for Radium Removal
}

\author{
Md. Shafiquzzaman*(D), Saleem S. AlSaleem (D, Husnain Haider, Mohammad T. Alresheedi and Hussein Thabit
}

Citation: Shafiquzzaman, M.; AlSaleem, S.S.; Haider, H.; Alresheedi, M.T.; Thabit, $\mathrm{H}$. Experimental Study for Sand Filter Backwash Water Management: Low-Cost Treatment for Recycling and Residual Sludge Utilization for Radium Removal. Water 2021, 13 , 2799. https://doi.org/10.3390/ w13202799

Academic Editor: Alicia Ronda Gálvez

Received: 2 September 2021

Accepted: 3 October 2021

Published: 9 October 2021

Publisher's Note: MDPI stays neutral with regard to jurisdictional claims in published maps and institutional affiliations.

Copyright: (c) 2021 by the authors. Licensee MDPI, Basel, Switzerland. This article is an open access article distributed under the terms and conditions of the Creative Commons Attribution (CC BY) license (https:// creativecommons.org/licenses/by/ $4.0 /)$.
Department of Civil Engineering, College of Engineering, Qassim University, Buraydah 51452, Saudi Arabia; sa.alsaleem@qu.edu.sa (S.S.A.); h.hussain@qu.edu.sa (H.H.); m.alresheedi@qu.edu.sa (M.T.A.); h.thabit@qu.edu.sa (H.T.)

* Correspondence: M.UzzaMan@qu.edu.sa

\begin{abstract}
Management of backwash water (BW) generated from sand filtration of groundwater naturally contaminated with iron $(\mathrm{Fe})$, manganese $(\mathrm{Mn})$, and radium $(\mathrm{Ra})$ remains a challenge worldwide. The present study investigated the effectiveness of a low-cost clay ceramic filter for BW recycling along with residual sludge utilization for Ra removal from BW. A 15 day continuous ceramic filtration process operated at a constant flux of $2000 \mathrm{~L} / \mathrm{m}^{2} / \mathrm{d}(83 \mathrm{LMH})$ showed $99 \%$ removal of Fe, Mn, and turbidity. The treated BW was found suitable for recycling back to the sand filters. Subsequently, the residual sand filter backwash sludge (BS) was collected, characterized by scanning electron microscopy (SEM) and X-ray diffraction, and examined as a potential adsorbent to the Ra. Results showed that the sludge constituted heterogeneous basic elements, with higher percentages of iron and manganese oxides. The sludge can be classified as typical mesoporous and poorly crystalline minerals consisting primarily of quartz and $\mathrm{Mn}_{2} \mathrm{O}_{3}$. Over $60 \%$ of $\mathrm{Ra}$ from the initial $2.1 \mathrm{bq} / \mathrm{L}$ could be removed by sludge in $30 \mathrm{~min}$ at neutral $\mathrm{pH}$. The adsorption kinetics of sludge described well by the pseudo-second order model and Ra adsorption on the sludge were mainly controlled by chemisorption rate-controlling steps, intraparticle diffusion, and external mass transfer processes. Treatment of BW by low-cost clay ceramic filters and the utilization the BS for Ra removal would be a sustainable sand filter BW management practice.
\end{abstract}

Keywords: sand filter; backwash water; backwash sludge; clay ceramic filter; recycling; radium adsorption

\section{Introduction}

A large amount of backwash water (BW) is produced, particularly from the sand filter backwash in the drinking water purification process for groundwater sources [1-3]. Globally, around $2-10 \%$ of treated water has been used for the backwashing process $[1,4]$. In the Kingdom of Saudi Arabia (KSA), around 26 million $\mathrm{m}^{3}$ of treated water is used for sand filter backwashing per annum, which is later discharged to land or the municipal sewerage system. In recent years, several studies have been carried out to explore the possibility of BW recycling using membrane filtration [3,5-8]. As the technology needs a high initial cost and consumes high energy for operations, it has limited application in most cases, including in KSA. A sustainable low-cost method and simple technology are needed for treating BW.

In our previous study [4], a simple low-cost clay ceramic filter, coupled with the coagulation and flocculation process, was evaluated for BW treatment. However, the coagulation and flocculation process complicates the treatment system, leading to extra costs for the chemicals used (coagulant) and consuming high energy (although relatively less than membrane systems). To further minimize initial cost and energy requirements, investigation of the efficacy of the direct filtration of BW using a low-cost clay ceramic 
filter might lead to a more sustainable solution. Furthermore, BW produced from water treatment plants (WTPs) contains a large amount of solids, known as sand filter backwash sludge (BS) [9]. The BS resulting from Fe and Mn (naturally occurring in groundwater sources) removal processes consists primarily of the particulate forms of Fe and Mn oxyhydroxides [10], with a negligible level of hazardous substances [10]. Since this sludge is produced in large quantities, its safe disposal remains a challenge. Hence BS reuse has drawn worldwide attention from researchers as a way to protect the environment and economize resources.

Groundwater contamination due to ubiquitously existing, naturally occurring minerals, metals, and radionuclides is a major concern for water regulators worldwide. Among the $\mathrm{Ra}$ isotopes, ${ }^{226} \mathrm{Ra}$, and ${ }^{228} \mathrm{Ra}$ are the most important, with a half-life of 5.75 and 1600 years, respectively. These isotopes can accumulate in plants, humans, and animals as well as transfer to animals and humans through the food chains [11]. In addition to being naturally occurring, human activities, including the oil and gas industry production [12], uranium mining [13], and phosphate fertilizers [14] can increase Ra concentration in the surface water and groundwater. Health impacts associated with $\mathrm{Ra}$ in drinking water supplies have constituted major concerns in the last few decades. Consumption of water containing a high level of Ra may cause genetic damage, which may lead to bone cancer in humans [15]. Consequently, the standard limit for several radionuclides in drinking water was set by many national and international authorities. For instance, a combined Ra $\left({ }^{226} \mathrm{Ra}+{ }^{228} \mathrm{Ra}\right)$ of $0.185 \mathrm{~Bq} / \mathrm{L}(5 \mathrm{pCi} / \mathrm{L})$ was regulated by the United States Environmental Protection Agency (USEPA) [16]. According to the world health origination (WHO) drinking water quality guidelines, the maximum contamination level (MCL) of radium isotopes is $1.0 \mathrm{~Bq} / \mathrm{L}$ for ${ }^{226} \mathrm{Ra}$ and $0.1 \mathrm{~Bq} / \mathrm{L}$ for ${ }^{228} \mathrm{Ra}$ [17].

The extent of the contamination level of radionuclides in groundwater has been extensively investigated in various countries, including KSA [18-21]. A significant level of naturally occurring radioactive material (particularly $\mathrm{Ra}$ ) in groundwater was reported in many studies. Groundwater is the primary source (more than $80 \%$ ) of the drinking water supply in KSA [22]. Therefore, the elevated level of Ra in drinking water sometimes affects the efficacy of treatment processes and is a primary concern of water suppliers [23]. Irrigation application of groundwater containing radioactive materials contaminates the soil and ultimately reaches the human body via soil to plant uptake [24]. Land disposal of BW containing Ra has also been found to be threatening to the natural environment. Consequently, WTP managers are eager to find sustainable treatment mechanisms for Ra removal from the plant influents (raw water).

Several methods, including chemical precipitation, lime softening, ion exchange, and reverse osmosis have been employed for removing radionuclides from water [25-27]. In recent years, adsorption-based materials such as clay, zeolite, and bentonite have received special attention in the removal of radionuclides from water because of their low cost and higher removal efficiency [28-30]. Fe and Mn based adsorbents have shown good adsorption properties for many heavy metals and radionuclides, including uranium (U) and $\mathrm{Ra}[31,32]$. Utilizing the water treatment backwash sludge (WTBS) as catalysts, coagulation reagents, and adsorbents for the removal of heavy metals from waters and wastewaters is a rational approach [10]. Previous studies reported that WTBS has a high potential to adsorb many biological and chemical pollutants from water and wastewater due to its specific properties, such as high porosity, amorphous phases, and the presence of Fe and $\mathrm{Al}$ hydroxides, which work as chelating agents $[33,34]$. Although WTBS has been extensively tested to remove heavy metals from the water, its efficiency for Ra removal has not been investigated thus far. Hence, simultaneous treatment of BW by a low-cost clay ceramic filter and reuse of the filter residual (WTBS) as adsorbent of Ra from the groundwater would be a sustainable solution for the management of BW. 
Our present study aims to perform the experimental study for sand filter BW management for water treatment facilities relying on naturally contaminated groundwater sources, like in KSA. The specific objectives are to (i) investigate the efficacy of a low-cost clay ceramic filter for BW treatment and subsequent recycling to sand filters, and (ii) develop and test the WTBS as an adsorbent for Ra removal from the groundwater.

\section{Materials and Methods}

\subsection{Conceptual Model for Sustainable BW Management}

Figure 1 illustrates a conceptual model for a sustainable water treatment BW management system. The model was primarily proposed to treat and recycle the BW and utilize the residual as an adsorbent for radioactive materials. The sand filter BW was first filtrated by a low-cost clay ceramic filter. The filtrated water was recirculated to the plant, but could be reused for other purposes, e.g., toilet flushing and agriculture. The BW filtration residual sludge (i.e., WTBS) was collected and processed to develop an adsorbent, which was then tested for Ra removal from the groundwater. Sand filter BW from a local WTP was collected to conduct the laboratory experiments.

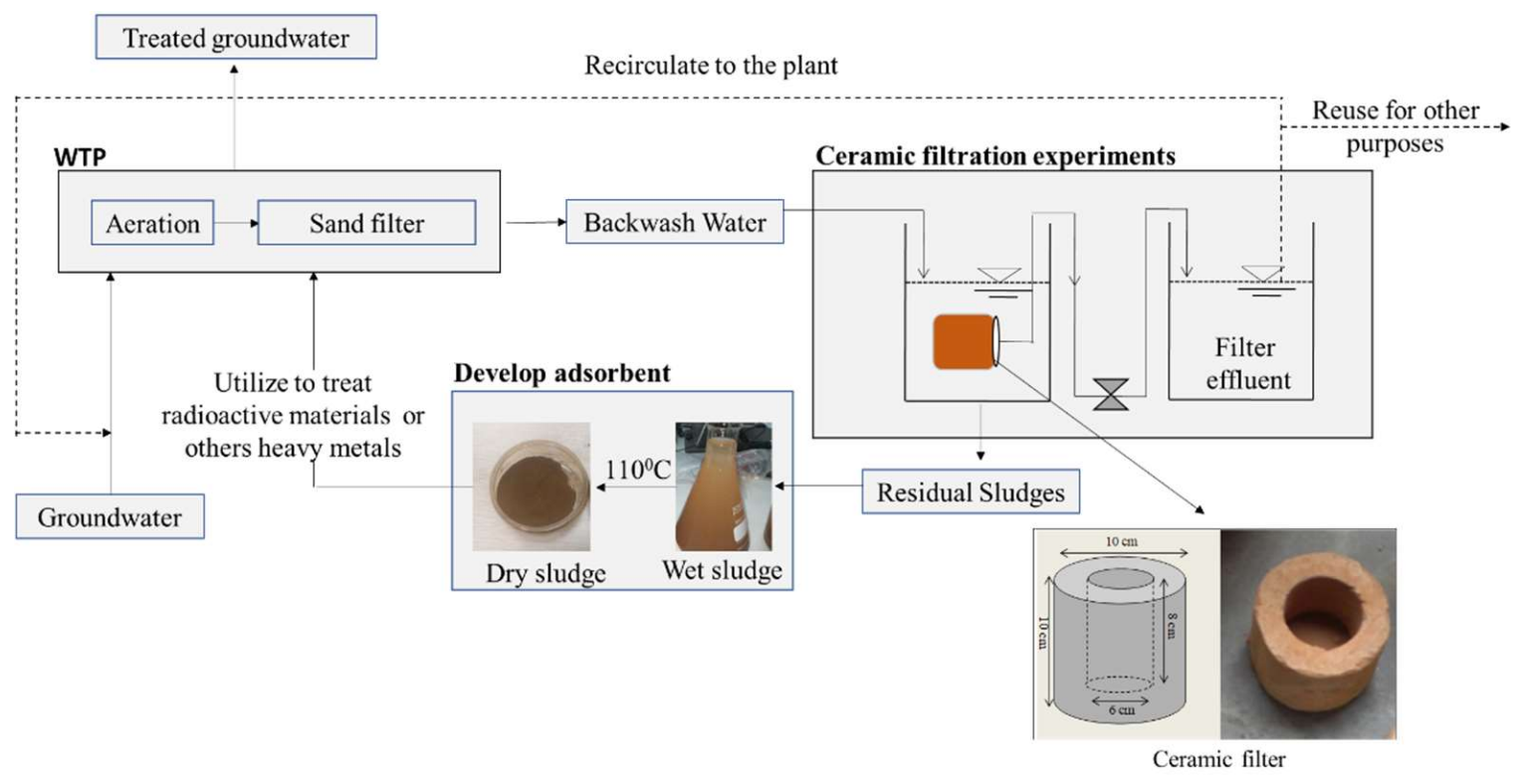

Figure 1. A conceptual model for sustainable BW management system.

\subsection{Collection of Backwash Water}

Backwash water samples were collected from the disposal point of Buraydah WTP located in Buraydah City, i.e., the capital of Qassim Province of KSA. Figure 2 illustrates the schematics of water treatment processes along with the sampling location. The plant operates by diffused air aeration of raw groundwater containing iron and manganese, followed by fixed bed sand filtration. In the subsequent steps, the cartridge filter then uses reverse osmosis to remove total dissolved solids. Filtered water is blended with reverse osmosis demineralized water to produce the final product, which complies with Saudi Arabian Water Quality Standards. For the present research, the samples were collected in a $50 \mathrm{~L}$ jar and brought back to the laboratory. Fresh samples were immediately analyzed and used for experiments without any pre-treatment. 


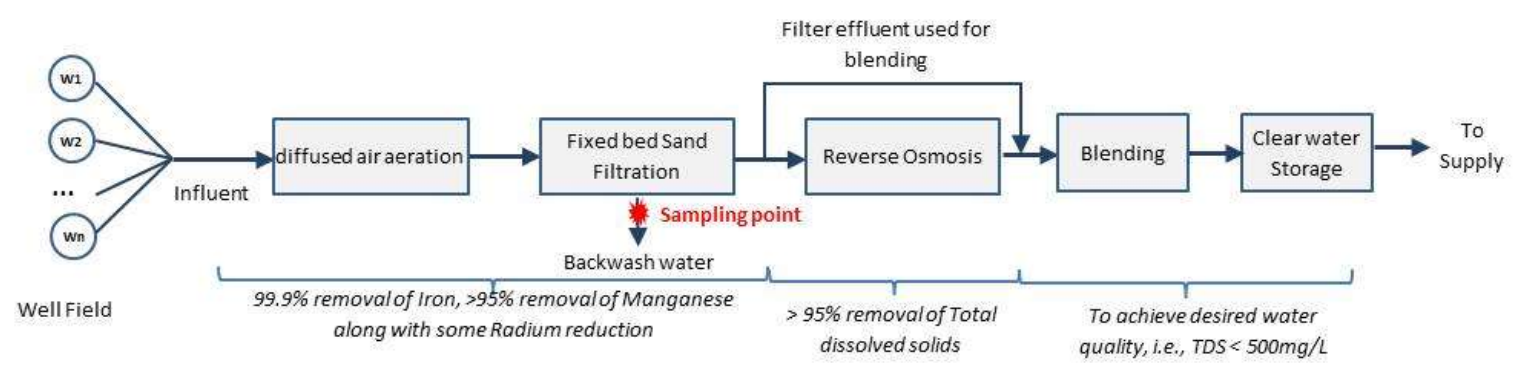

Figure 2. Schematic diagram of water treatment processes in Buraydah, Qassim, Saudi Arabia.

\subsection{Clay Ceramic Filter}

The cylindrical shaped clay ceramic filter used in this study was manufactured using locally available clay soil and rice bran (see bottom right of Figure 1). The manufacturing process was adapted from our previous study [35]. Briefly, clay soil and rice bran were mixed at a ratio of 80:20 by weight. Water was added as needed to make the dough and cast in a cylindrical shape mold to make the hollow cylindrical shape with a closed one-end clay ceramic filter. The filter was sun-dried for $48-72 \mathrm{~h}$, followed by firing in a muffle furnace in a small-scale pottery kiln at $900{ }^{\circ} \mathrm{C}$ for $4-5 \mathrm{~h}$. The hollow clay ceramic filter is open on one side, $10 \mathrm{~cm}$ high, and holds a thickness of $2 \mathrm{~cm}$ (Figure 1). The filter has a pore size of $1-5 \mu \mathrm{m}$, with an active surface area of $0.039 \mathrm{~m}^{2} /$ filter [35].

\subsection{Ceramic Filtration Experiments}

A lab-scale continuous ceramic filtration system was developed to investigate the contaminant removal efficiency of the low-cost clay ceramic filter. Figure 1 presents the schematics of the experimental setup and ceramic filtration experiment position. The low-cost clay ceramic filter was submerged in a rectangular tank (filtration tank) made of thermoplastic glass. The filter was sealed with a rubber cap and connected with an effluent tube to the effluent tank. The filtration was carried out continuously for 15 days at a fixed flux of $2000 \mathrm{~L} / \mathrm{m}^{2} / \mathrm{d}(83 \mathrm{LMH})$ using a suction pump. Influent and effluent water samples were regularly collected for water quality analysis.

\subsection{Water Treatment Backwash Sludge (WTBS)}

Following the filtration experiments, the residuals remaining in the filtration tank, known as WTBS, were collected and kept for $24 \mathrm{~h}$ settling, as shown in Figure 1. Subsequently, the settled sludge was separated and oven dried for $72 \mathrm{~h}$ at $110^{\circ} \mathrm{C}$. Finally, the sludge was ground manually, passed through a $300 \mu \mathrm{m}$ sieve to remove large particles, and stored in a desiccator for characterization and adsorption experiments.

\subsection{Characterization of WTBS}

Elemental analysis of the WTBS was measured, including total concentrations of $\mathrm{Fe}$, $\mathrm{Al}, \mathrm{Mn}, \mathrm{As}, \mathrm{Zn}, \mathrm{Pb}, \mathrm{Cu}, \mathrm{Cd}$, and $\mathrm{Cr}$, using an inductively coupled plasma atomic emission spectroscopy (ICP-AES Thermo Scientific, Waltham, MA, USA). Prior to ICP-AES analysis, the WTBS samples were digested with Aqua regia solution comprising a 3:1 mixture of hydrochloric acid and nitric acid. The surface morphology of the WTBS was assessed using FEI Quanta SEM scanning Electron Microscopy (SEM). The SEM analysis was performed by applying an accelerating voltage of $5 \mathrm{kV}$ with various magnification essays. The $\mathrm{X}$-ray diffraction technique (XRD) using ULTIMA IV/Rigaku was applied to assess the crystalline structure of the WTBS samples. The main mineral phases of the WTBS were identified by the phase analysis of the samples using XRD methods. The sweeping speed of the samples was maintained at $1^{\circ} / \mathrm{min}$ between $2 \theta=0^{\circ}$ to $70^{\circ}$. 


\subsection{Adsorption Kinetics Experiments}

Adsorption studies were carried out in a batch mode, using the A\&F jar test apparatus (JM4, Novatech International, Kingwood, TX, USA) at $140 \mathrm{rpm}$. Natural groundwater containing $2.66 \mathrm{bq} / \mathrm{L}$ of total $\mathrm{Ra}\left({ }^{226} \mathrm{Ra}\right.$ and $\left.{ }^{228} \mathrm{Ra}\right)$ was used as the source of Ra solution. The Ra solution was mixed with $0.1 \mathrm{~g}$ of WTBS powder in $1000 \mathrm{~mL}$ glass beakers for 5,10 , $15,30,60$, and $120 \mathrm{~min}$. Experiments were conducted under neutral $\mathrm{pH}(7.2 \pm 0.26)$ and room temperature $\left(26-28^{\circ} \mathrm{C}\right)$. At specified time intervals, samples were taken and filtered through the glass fiber filter paper (ADVANTEC GS 50) and the concentrations of residual Ra were measured. All experiments were conducted in duplicate, and the average values are presented.

\subsection{Kinetic Adsorption Models}

Pseudo-first-order (PFO) and pseudo-second-order (PSO) kinetic models along with intraparticle and external diffusion models were applied to the adsorption data to understand the sorption kinetic of Ra by WTBS. These kinetics models are well known and give insight into the rate and the mechanism of the adsorption process [36,37]. Thus, they were applied for a detailed understanding of the adsorption process of Ra onto the WTBS. Table 1 shows the equations for the kinetics adsorption models used in this study [36-38].

Table 1. Equations for kinetics adsorption models.

\begin{tabular}{cll}
\hline Model Name & \multicolumn{1}{c}{ Mathematical Model } & \multicolumn{1}{c}{ Model Parameters Definition } \\
\hline Pseudo-first-order model & $\begin{array}{l}d q_{t} / d t=k_{t}\left(q_{e}-q_{t}\right) \\
\text { Integrated from } \\
\ln \left(q_{e}-q_{t}\right)=\ln q_{e}=k_{1} t\end{array}$ & $\begin{array}{l}q_{e}=\text { amount of Ra adsorbed at equilibrium time }(\mathrm{bq} / \mathrm{g}) \\
q_{t}=\text { amount of Ra adsorbed at time } \mathrm{t}(\mathrm{bq} / \mathrm{g}) \\
k_{1}=\text { pseudo-first-order rate constant }(/ \mathrm{min})\end{array}$ \\
\hline Pseudo-second-order model & $\begin{array}{l}\text { d } q_{t} / \mathrm{d} t=k_{2}\left(q_{e}-q_{t}\right)^{2} \\
1 / q_{t}=1 / k_{2} q_{e}^{2}+1 / q_{e} t \\
\text { Initial adsorption rate } \\
h_{0}=k_{2} q_{e}^{2}\end{array}$ & $k_{2}=$ pseudo-second-order rate constant $(\mathrm{g} / \mathrm{mg} / \mathrm{min})$ \\
\hline Intraparticle diffusion model & $\begin{array}{l}q_{t}=k_{p} t^{1 / 2}+C \\
\text { External diffusion model }\end{array}$ & $\begin{array}{l}k_{p}=\text { equilibrium rate constant of intraparticle diffusion } \\
\text { (bq/g.min0.5) } \\
C=\text { intraparticle diffusion model constant (bq/g) }\end{array}$ \\
\hline $\ln \left(c_{t} / c_{0}\right)=-k_{e x} t$ & $\begin{array}{l}k_{e x}=\text { equilibrium rate constant of external diffusion }(/ \mathrm{min}) \\
c_{0}=\text { initial concentration of Ra in the solution (bq/L) } \\
c_{t}=\text { concentration of Ra in the solution at time } \mathrm{t}(\mathrm{bq} / \mathrm{L})\end{array}$ \\
\hline
\end{tabular}

\subsection{Water Quality Analysis}

A radiochemical method was employed to measure the Ra isotope. The samples were prepared by co-precipitation of Ra isotopes with a barium carrier followed by mixing with gelling scintillating cocktail LumaGel ${ }^{\mathrm{TM}}$. Finally, the Ra was measured in a low-level liquid scintillation spectrometer Quantulus ${ }^{\mathrm{TM}}$. All other physical and chemical analyses of water samples were performed according to the standard method [39]. $\mathrm{pH}$ and electrical conductivity (EC) were measured using a potable meter (HMP6, HACH). Turbidity was measured using the turbidity meter (2100Q, HACH). A potable Ultra-meter II 6P (6PIIFCE, Myron L, Carlsbad, CA, USA) was used to measure TDS. Alkalinity was measured using the per-standard titration method. Total Fe and Mn were measured using a spectrophotometer (HACH DH-5000) according to the $\mathrm{HACH}$ method. Chloride $(\mathrm{Cl})$ was measured by titration with potassium chromate and silver nitrate solutions. Total hardness, calcium $(\mathrm{Ca})$, and magnesium $(\mathrm{Mg})$ were measured using $\mathrm{HACH}$ test kits according to the retraction methods specified by HACH. Total suspended solids (TSS) were measured by the gravimetric method. 


\subsection{Econmomic Analysis of the Ceramic Filtration Process}

The economic analysis of the low-cost ceramic filtration process was performed by estimating the costs of major components, including the filter, feed pump, suction pump, as well as the operating (electricity) cost of the pumps. The total annualized cost can be estimated using Equation (1):

$$
\mathrm{C}_{\text {total }}=\mathrm{C}_{\text {Afilter }}+\mathrm{C}_{\text {Apump }}+\mathrm{C}_{\text {Aop }}
$$

The annualized filter cost $\left(\mathrm{C}_{\mathrm{Afilte}} \mathrm{r}\right.$, \$/year), pump cost $\left(\mathrm{C}_{\mathrm{Apump}}\right.$, $\$$ /year), and operating costs of the pump ( $\mathrm{C}_{\text {Aop }}, \$$ /year) were estimated using a method given by Shethi and Winsner [40]. The feed rate was selected based on $1-10 \%$ of the total freshwater production of the WTP. The cost of the clay ceramic filter $\left(\$ 30 / \mathrm{m}^{2}\right)$ was taken from a previous study [35]. The lifespan of the clay ceramic filter was assumed to be 1 year. Based on the present study, the permeate flux $\left(2000 \mathrm{~L} / \mathrm{m}^{2} / \mathrm{d}\right)$ was adapted from the continuous filtration data, and the operating pressure was calculated to be $3.5 \mathrm{KPa}$.

\section{Results}

\subsection{Characteristics of $B W$ and Treatment Efficiency}

The treatability of BW using a low-cost clay ceramic filter was investigated in a continuous filtration experiment, and the results are presented in Figure 3. Analysis indicated that the turbidity of BW was very high $(635 \pm 253 \mathrm{NTU})$, containing significantly higher concentrations of $\mathrm{Fe}(54.9 \pm 24.0 \mathrm{mg} / \mathrm{L})$ and $\mathrm{Mn}(7.6 \pm 4.8 \mathrm{mg} / \mathrm{L})$. Figure 2 presents the removal performance of turbidity, Fe, and Mn by the low-cost clay ceramic filter. More than $99 \%$ of the turbidity, Fe, and Mn was removed by simple ceramic filtration. The average effluent concentrations were as follows: turbidity $<5 \mathrm{NTU}, \mathrm{Fe}<0.9 \mathrm{mg} / \mathrm{L}$, $\mathrm{Mn}<0.5 \mathrm{mg} / \mathrm{L}$; these correspond to more than $99 \%$ average removal from the raw BW.

As the BW contained the particulate forms of Fe and Mn oxy-hydroxides, the microporous clay ceramic filter effectively separated these during the filtration process, resulting in very low concentrations of $\mathrm{Fe}, \mathrm{Mn}$, and turbidity in the effluent. As expected, high TSS removal (>99\%) was also achieved. The removal of other parameters, including TDS, conductivity, hardness, $\mathrm{Ca}, \mathrm{Mg}$, and $\mathrm{Si}$ were not significant and remained almost unchanged. Subsequently, the residual sludge in the filter was collected, processed, characterized, and tested for Ra removal from the groundwater. 
(a)

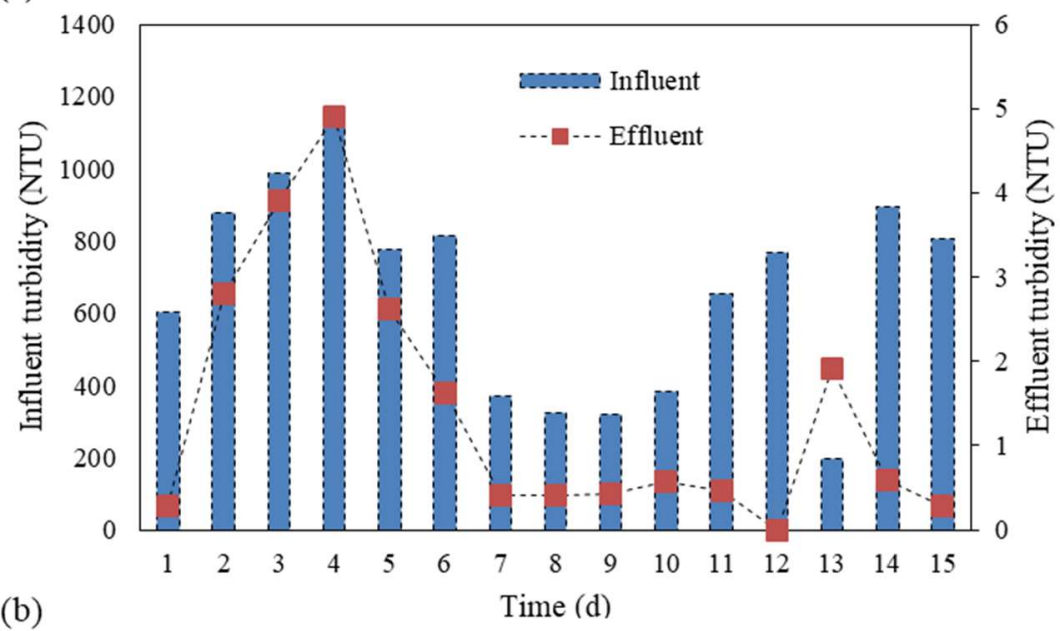

(b)

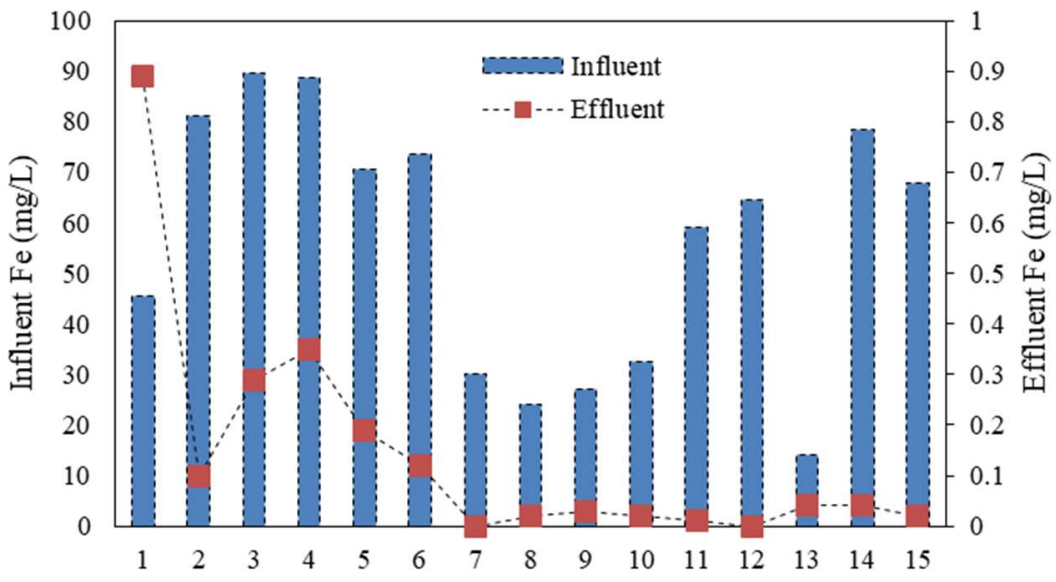

(c)

Time (d)

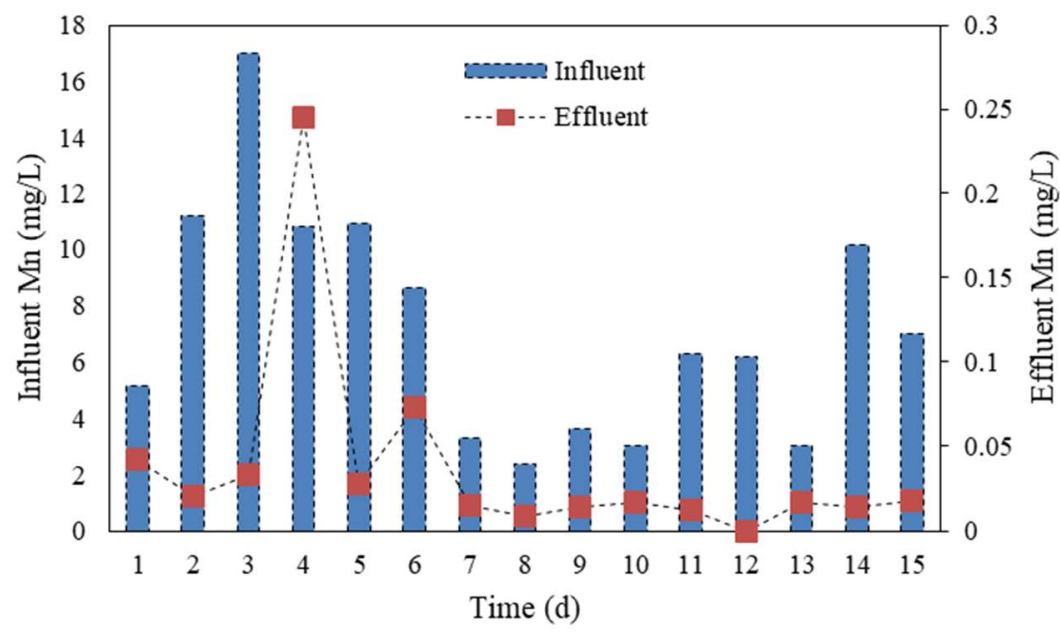

Figure 3. Removal performances of (a) turbidity, (b) Fe, and (c) Mn by using continuous ceramic filtration experiments.

\subsection{Characterizations of WTBS}

The diffused aeration of raw groundwater, followed by a fixed bed sand filter, produced insoluble WTBS containing hydroxides and oxides of Fe and Mn. Elemental analysis of the WTBS as presented in Table 2 reveals that $\mathrm{Fe}, \mathrm{Mn}$, and sodium (Na) compounds were the main constituents, accounting for $61.4 \%, 14.05 \%$, and $12.6 \%$, respectively. High concentrations of Fe and Mn indicated the presence of their oxide and oxo-hydroxide 
forms. Moreover, a significant amount of $\mathrm{Mg}(5.2 \%), \mathrm{Ca}(2.4 \%), \mathrm{K}(2.0 \%)$, and $\mathrm{Zn}(1 \%)$ was observed with Fe and Mn in the WTBS. The presence of Ca and Mg suggested the formation of amorphous calcium carbonate and calcite precipitate in the WTBS.

Table 2. Elemental compositions of the WTBS.

\begin{tabular}{ccc}
\hline Elements & Concentrations $(\mathrm{mg} / \mathrm{L})$ & \% Content in WTBS \\
\hline $\mathrm{Fe}$ & 9.678 & 61.419 \\
$\mathrm{Mn}$ & 2.215 & 14.057 \\
$\mathrm{Na}$ & 1.992 & 12.640 \\
$\mathrm{Mg}$ & 0.829 & 5.264 \\
$\mathrm{Ca}$ & 0.387 & 2.453 \\
$\mathrm{~K}$ & 0.326 & 2.070 \\
$\mathrm{Zn}$ & 0.159 & 1.010 \\
$\mathrm{Al}$ & 0.072 & 0.459 \\
$\mathrm{Ni}$ & 0.043 & 0.276 \\
$\mathrm{~V}$ & 0.008 & 0.050 \\
$\mathrm{Cu}$ & 0.008 & 0.049 \\
$\mathrm{Cd}$ & 0.007 & 0.046 \\
$\mathrm{Rb}$ & 0.007 & 0.045 \\
$\mathrm{Li}$ & 0.007 & 0.042 \\
$\mathrm{Cr}$ & 0.006 & 0.037 \\
$\mathrm{~Pb}$ & 0.005 & 0.033 \\
$\mathrm{Se}$ & 0.003 & 0.021 \\
$\mathrm{Co}$ & 0.003 & 0.018 \\
$\mathrm{As}$ & 0.001 & 0.009 \\
\hline
\end{tabular}

The SEM image is an effective method to examine surface morphology in the microregion of environmental samples [41]. The SEM image, presented in Figure 4, showed that the WTBS is irregular in shape and size. The grains are aggregated, with a micro-sized, porous, and smoothly layered structure. Therefore, the WTBS can be classified as a typical mesoporous material with a broad grain size distribution. Usually, the effectiveness of the adsorption process is highly dependent on the morphology of the adsorbent. However, the $\mathrm{pH}$ of the adsorbent plays a significant role in the adsorption process, particularly in the case of chemisorption and ion exchange reactions. Anion adsorption is favorable under the $\mathrm{pH}$ below pHpzc ( $\mathrm{pH}$ at the potential of zero charges), while cations adsorb effectively above pHpzc [10]. The pH of WTBS was measured as 7.2.
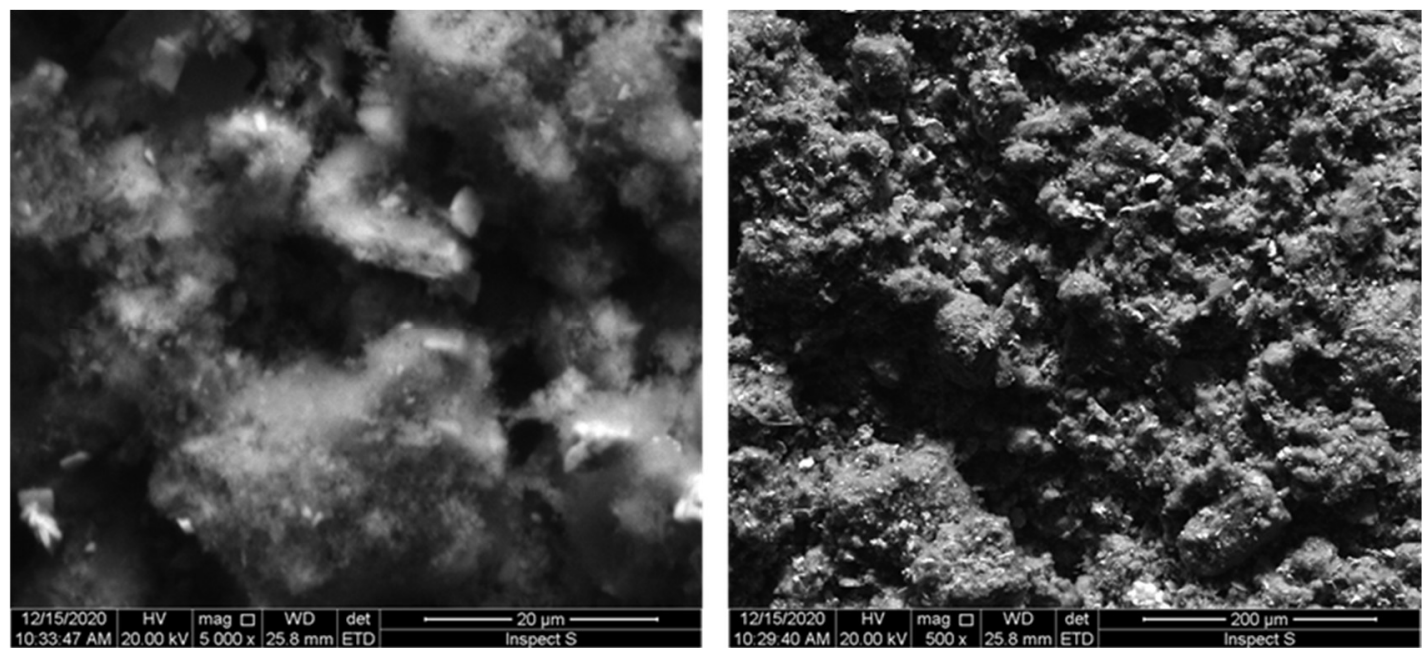

Figure 4. SEM images of WTBS: left image (surface at 5000× magnification); right image (surface at 500× magnification). 
In Figure 5, the diffraction pattern shows that the predominant phases were poorly crystalline minerals consisting primarily of quartz and $\mathrm{Mn}_{2} \mathrm{O}_{3}$. The observed peaks of crystalline form indicate the presence of quartz (JCPDS 47-1301) and $\mathrm{Mn}_{2} \mathrm{O}_{3}$ (JCPDS 411442). A similar XRD pattern of water treatment residuals containing quartz and $\mathrm{Mn}_{2} \mathrm{O}_{3}$ was also reported in a previous study [10]. The results of the XRD pattern imply that the Fe oxides present in the WTBS were amorphous. Two primary forms, including ferrihydrite and feroxyhyte $(\mathrm{d} 0-\mathrm{FeOOH})$, might be the most probable products of the studied WTBS minerals.

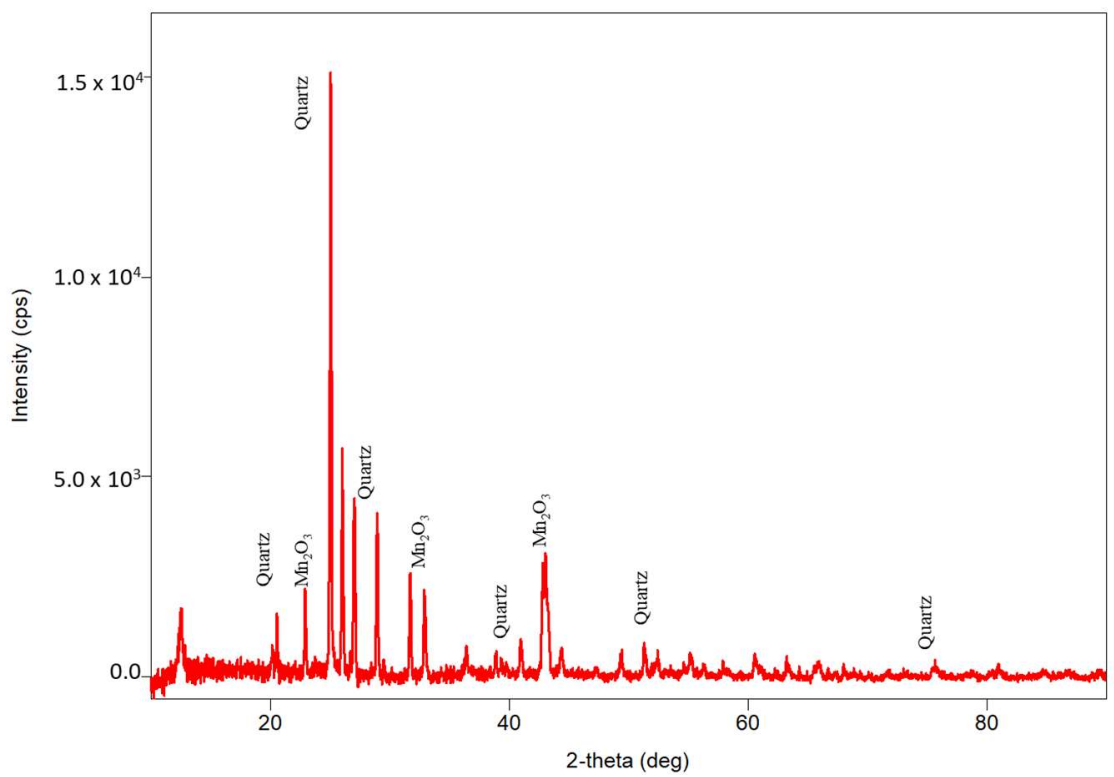

Figure 5. X-ray diffraction pattern of WTBS.

\subsection{Kinetic Studies of Ra Removal by WTBS}

Figure 6 presents the kinetic results of Ra adsorption on WTBS at neutral pH 7.5-8.0. The adsorption of Ra is fast and effective during the first $30 \mathrm{~min}$, adsorbing around $58.3 \%$, with a residual $\mathrm{Ra}$ of $1.11 \mathrm{~Bq} / \mathrm{L}$, which was then decelerated until $120 \mathrm{~min}$ and remained almost steady to $61 \%$ removal, with a residual $\mathrm{Ra}$ of $1.04 \mathrm{~Bq} / \mathrm{L}$. However, the adsorption never reached $100 \%$, indicating that the effectiveness of Ra removal was dependent on the initial concentrations of Ra. Nevertheless, the residual Ra almost met the WHO standard $(1.0 \mathrm{~Bq} / \mathrm{L})$ of maximum contaminant level (MCL) in drinking water. The adsorption equilibrium was reached at $120 \mathrm{~min}$, which was presumed to be the equilibrium time for Ra adsorption. Relatively shorter equilibrium time indicates a higher concentration gradient between the bulk solution and the adsorption surface [10]. The radium adsorption efficiency $(61 \%)$ of WTBS observed in this study was comparable with some of the previously studied adsorbents, where the reported removal efficiency of Ra 226 from the contaminated ground water was $60-69 \%$ for Montmorillonite, $33-45 \%$ for biochar, and around $50 \%$ for polyacrylonitrile and clinoptilolite adsorbents [30,42]. However, for a detailed comparison, a further study including batch adsorption isotherms and the influence of $\mathrm{pH}$ and temperature on Ra removal by the WTBS is recommended. 


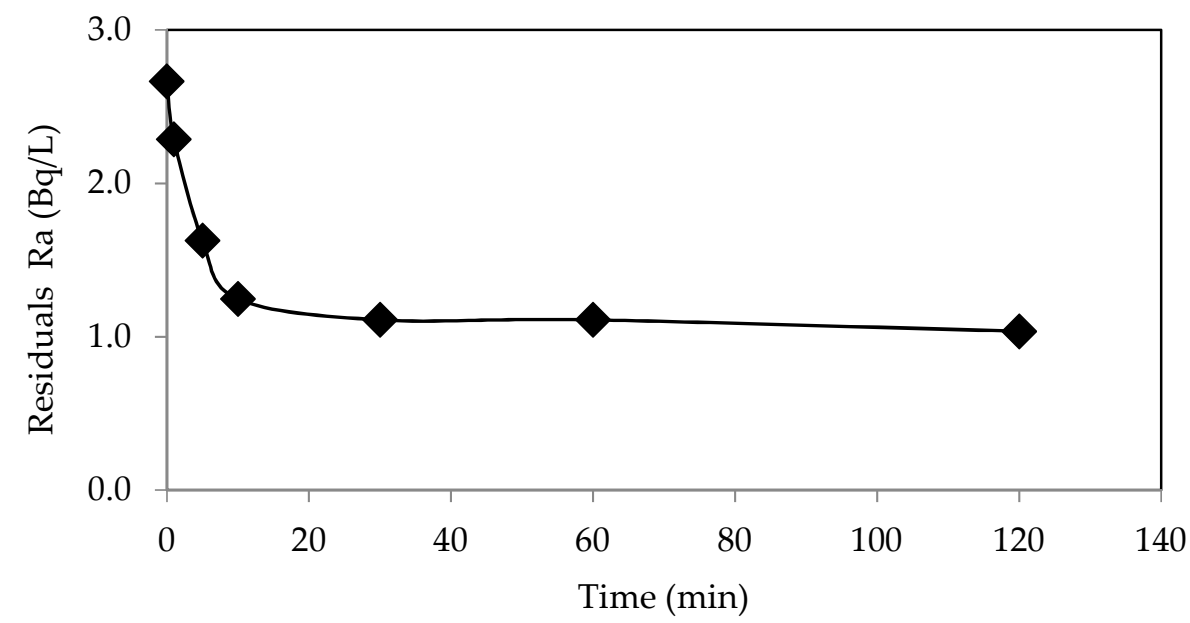

Figure 6. Removal of Ra by WTBS with time.

The adsorption rate, process mechanism, and rate-limiting step were determined by modeling the experimental data using the kinetic equations as described in Table 1. The adsorption data fitted well with the pseudo-second-order adsorption model with the correlation coefficient $\mathrm{R}^{2}$ of 0.999 (Figure 7a and Table 3), emphasizing that Ra adsorption on the WTBS is primarily governed by chemisorption rate-controlling mechanism. Equilibrium sorption capacities and adsorption rate were calculated from the model. For the PSO model, the calculated equilibrium adsorption qe $(16.47 \mathrm{~Bq} / \mathrm{g})$ was close to the experimental qe value of $16.28 \mathrm{~Bq} / \mathrm{g}(\mathrm{PFO})$. The reaction rate constant $\left(\mathrm{k}_{2}\right)$ was calculated to be $0.028 \mathrm{~g} / \mathrm{bq}$.min, whereas the initial adsorption rate $\left(\mathrm{h}_{0}\right)$ was found to be $7.77 \mathrm{~Bq} / \mathrm{g}$.min. Two clearly distinct phases were observed during Ra adsorption onto WTBS: rapid adsorption at the initial phase over the first $30 \mathrm{~min}$ (about $58 \%$ adsorption), followed by a steady adsorption stage to become equilibrium until $120 \mathrm{~min}$. At the initial phase, an instantaneous and faster surface diffusion process took place due to the availability of an adequate adsorption surface of WTBS. A gradual adoption at the second phase was attributed to the slow intraparticle diffusion between the adsorbate (Ra) and the WTBS active sites.

Table 3. Kinetic parameters for Radium adsorption on WTBS.

\begin{tabular}{|c|c|c|}
\hline Models & Parameters & Values \\
\hline & $\begin{array}{c}\text { ter kinetic model } \\
\mathrm{q}_{\mathrm{e}} \exp (\mathrm{bq} / \mathrm{g}) \\
\mathrm{q}_{\mathrm{e}} \mathrm{cal}(\mathrm{bq} / \mathrm{g}) \\
\mathrm{k}_{1}(/ \mathrm{min}) \\
\mathrm{R}^{2}\end{array}$ & $\begin{array}{c}16.28 \\
8.00 \\
0.049 \\
0.72\end{array}$ \\
\hline & $\begin{array}{c}\text { der kinetic model } \\
\mathrm{qe}_{\mathrm{e}} \text { cal }(\mathrm{bq} / \mathrm{g}) \\
\mathrm{k}_{2}(\mathrm{~g} / \mathrm{bq} \cdot \mathrm{min}) \\
\mathrm{R}^{2} \\
\mathrm{~h}_{0}(\mathrm{bq} / \mathrm{g} \cdot \mathrm{min})\end{array}$ & $\begin{array}{c}16.47 \\
0.028 \\
0.999 \\
7.77\end{array}$ \\
\hline & $\begin{array}{l}\text { iffusion model } \\
\mathrm{k}_{\mathrm{p} 1}\left(\mathrm{bq} / \mathrm{g} \cdot \mathrm{min}^{0.5}\right) \\
\mathrm{c}_{1}(\mathrm{bq} / \mathrm{g}) \\
\mathrm{R}^{2} \\
\mathrm{k}_{\mathrm{p} 2}\left(\mathrm{bq} / \mathrm{g} \cdot \mathrm{min}^{0.5}\right) \\
\mathrm{c}_{1}(\mathrm{bq} / \mathrm{g}) \\
\mathrm{R}^{2}\end{array}$ & $\begin{array}{c}4.847 \\
-0.907 \\
0.995 \\
0.141 \\
13.72 \\
0.848\end{array}$ \\
\hline & $\begin{array}{c}\text { usion model } \\
\mathrm{k}_{\mathrm{ex}}(/ \mathrm{min}) \\
\mathrm{R}^{2}\end{array}$ & $\begin{array}{l}0.280 \\
0.981\end{array}$ \\
\hline
\end{tabular}


(a)
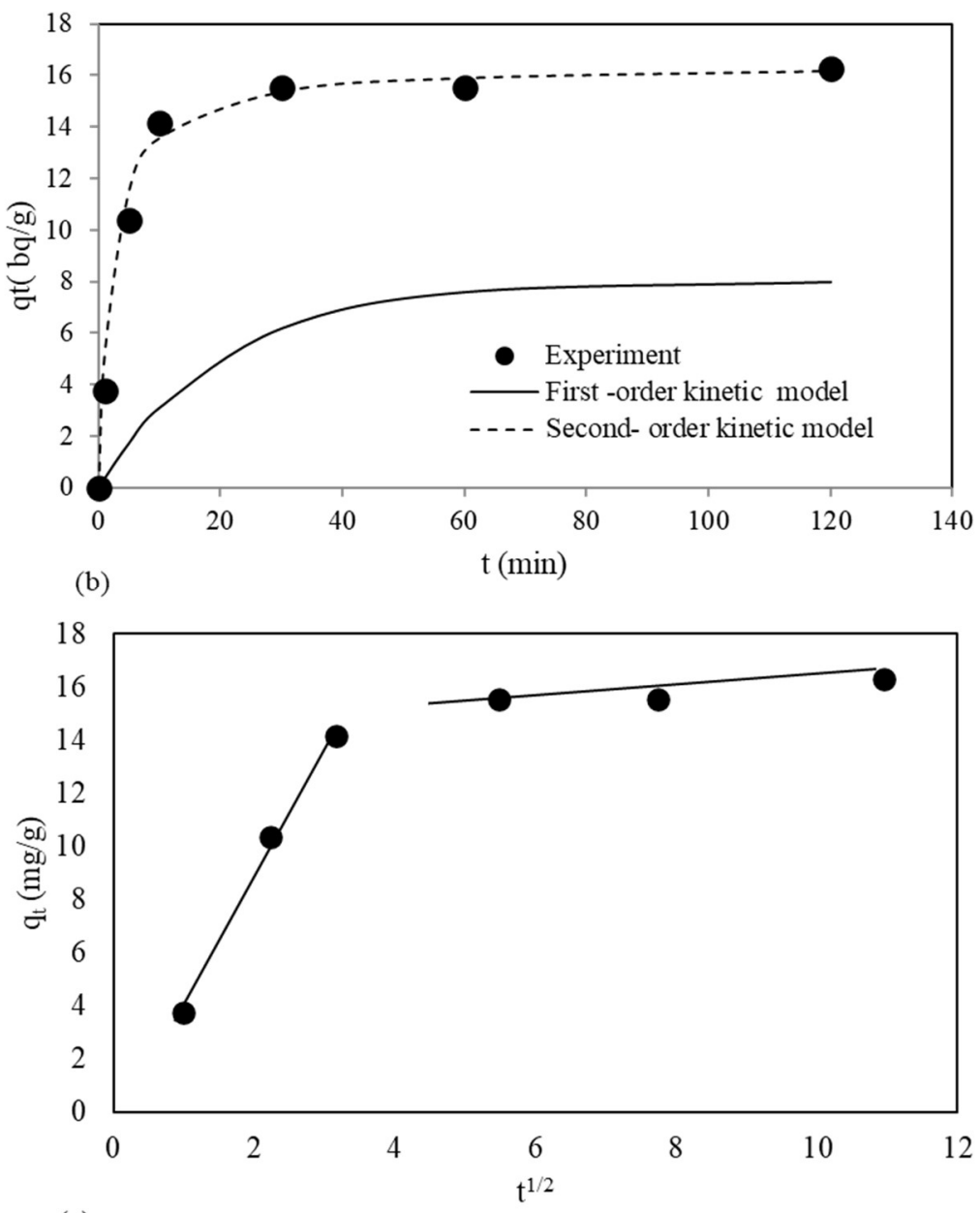

(c)

$\mathrm{t}(\mathrm{min})$

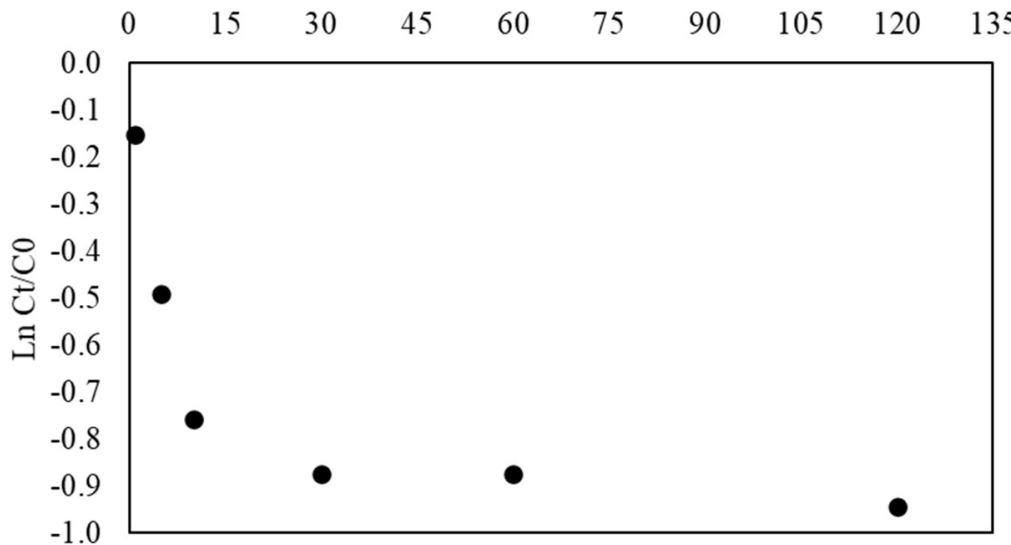

Figure 7. (a) Kinetics of data and fitted models of radium adsorption of WTBS, (b) plot of the intraparticle diffusion model and, (c) plots of the external diffusion model.

To verify this supposition, the kinetics data were further analyzed using various adsorption diffusion models, including external film diffusion and intraparticle diffusion models. The diffusion models provide a better insight into the mechanism of the process, including the determination of rate-limiting steps. Several studies have shown that adsorption is the rate-controlling process if the plot of $\mathrm{q}_{\mathrm{t}} \mathrm{vs}$. $\mathrm{t}^{1 / 2}$ of the intraparticle diffusion model is linear and passes through the origin [10]. If the plot represents multilinearly, this indicates that the adsorption is a multi-stage process involving various limiting factors 
at different steps of the process. As can be seen for the Ra adsorption, the intraparticle diffusion is multilinear and has two straight lines, which did not pass through the origin (Figure $7 \mathrm{~b}$ ). Thus different processes at subsequent steps are involved and control the Ra adsorption rate by WTBS [43]. The calculated rate constant $k_{p 1}$ value was higher than the $\mathrm{k}_{\mathrm{P} 2}$ value (Table 4), suggesting that the intraparticle diffusion was the rate-limiting step for the adsorption of Ra onto the WTBS. Moreover, the deflection of the straight lines from the point of origin (Figure $7 \mathrm{~b}$ ) indicated that other steps, such as surface adsorption, may also be involved in the rate-limiting step in the adsorption process. For more insight, the kinetics data were also analyzed using the external diffusion (ED) model (Table 3, Figure $7 \mathrm{c}$ ). If the linear form of the ED model $\left(\ln C_{t} / C_{0}\right.$ vs. $\left.t\right)$ passes through the origin, then the process is determined by the transport of adsorbate through the boundary layer [44]. As can be seen, at the initial stage of the process (first $15 \mathrm{~min}$ ), the plot of the ED model includes straight lines, but they do not pass through the origin. These results suggest that the chemisorption and inner-sphere complexation is a crucial phenomenon affecting the rate of the process. Overall, the kinetic data suggested that Ra adsorption by WTBS is attributed to a combination process including chemisorption rate-controlling steps, intraparticle diffusion, and external mass transfer processes.

Table 4. Contaminant removal performance of low-cost clay ceramic filters compared to WHO standards.

\begin{tabular}{ccccc}
\hline Parameter & Influent & Effluent & $\begin{array}{c}\text { WHO Reuse } \\
\text { Standard [45] }\end{array}$ & $\begin{array}{c}\text { WHO Drinking } \\
\text { Water Standard [43] }\end{array}$ \\
\hline PH & $7.2 \pm 0.26$ & $7.2 \pm 0.15$ & $6.0-9.0$ & $6.5-8.5$ \\
Alkalinity (mg/L) & $131 \pm 5.0$ & $155 \pm 27$ & - & - \\
Turbidity (NTU) & $635 \pm 253$ & $0.95 \pm 1.2$ & 5 & $<1$ \\
TSS (mg/L) & $165 \pm 21$ & $0.31 \pm 0.41$ & - & - \\
TDS (mg/L) & $770 \pm 5$ & $788 \pm 13$ & - & 500 \\
Conductivity ( $/ \mathrm{SS} / \mathrm{cm})$ & $1545 \pm 10$ & $1648 \pm 71$ & - & - \\
Hardness (mg/L) & $303 \pm 6$ & $326 \pm 21$ & - & - \\
Ca (mg/L) & $82.6 \pm 2.0$ & $110 \pm 17$ & - & - \\
Mg (mg/L) & $23 \pm 0.7$ & $18.0 \pm 3.0$ & - & 0.3 \\
Fe (mg/L) & $54.9 \pm 24.0$ & $0.08 \pm 0.18$ & 5 & 0.1 \\
Mn (mg/L) & $7.6 \pm 4.8$ & $0.03 \pm 0.045$ & 0.2 & - \\
Si (mg/L) & $18.3 \pm 2.1$ & $18.3 \pm 2.5$ & - & \\
\hline
\end{tabular}

\section{Discussion}

The quality of the treated BW obtained from the filtration system is presented in Table 4 . The removal performance was highly effective at the optimal flux conditions, achieving almost $99.9 \%$ removal of turbidity, $\mathrm{Fe}$, and $\mathrm{Mn}$ from the raw BW. Table 4 also compares the effluent with the WHO standards for reuse applications as well as for the drinking water. All the measured parameters in the effluent were lower than the recommended limits, showing that the low-cost ceramic filtration system is a sustainable option for BW recycling. Additionally, the ceramic filtration system used to reclaim backwash flow could significantly reduce the WTP potential for environmental impact and recover valuable resources, including BS. Overall, it can eliminate all wastewater effluent (i.e., BW) from the plant. The study found that if a WTP produced drinking water at a rate of $100,000 \mathrm{~m}^{3}$ / day with a $10 \%$ backwash discharge, the ceramic filtration system is likely to treat approximately $10,000 \mathrm{~m}^{3} /$ day for reclamation. Furthermore, it was calculated that approximately $1650 \mathrm{~kg}$ of BS can be produced daily from $10,000 \mathrm{~m}^{3}$ of BW (based on the TSS value $165 \mathrm{mg} / \mathrm{L}$ presented in Table 4), which can treat approximately 130,000 $\mathrm{m}^{3}$ of groundwater containing $2 \mathrm{bq} / \mathrm{L}$ of radium (calculated based on the equilibrium data $\mathrm{qe}=16.47 \mathrm{bq} / \mathrm{g}$ of kinetics adsorption, presented in Table 3).

Table 5 shows that the total annualized cost for the treatment of BW decreased from 0.021 to $0.011 \mathrm{US} \$ / \mathrm{m}^{3}$ feed as the feed rate increased from 1000 to $10,000 \mathrm{~m}^{3} /$ day. The lowest cost contribution was achieved at $5.5-13 \%$ of the operating cost. A filter cost 
contribution of approximately $55-68 \%$ remained relatively consistent with the feed rate. As the feed rate decreased, the pump's cost contribution increased from 18 to $39 \%$. The overall cost of the present study was found to be lower than the previously studied microfiltration systems.

Table 5. The cost of water production of the ceramic filtration process for BW treatment at different feed rates.

\begin{tabular}{ccccc}
\hline \multirow{2}{*}{$\begin{array}{c}\text { Feed Flow } \\
\left(\mathbf{m}^{3} / \text { day) }\right.\end{array}$} & $\begin{array}{c}\text { Total Cost } \\
\text { (US } \mathbf{\$} / \mathbf{m}^{\mathbf{3}} \text { Feed) }\end{array}$ & Filter Cost & Pump Cost & $\begin{array}{c}\text { Operating } \\
\text { (Energy Cost) }\end{array}$ \\
\cline { 3 - 5 } & & 55 & 39 & 5.5 \\
$1000(1 \%)$ & 0.021 & 58 & 35 & 6.3 \\
$1500(1.5 \%)$ & 0.018 & 62 & 30 & 7.5 \\
$2500(2.5 \%)$ & 0.015 & 66 & 24 & 9.5 \\
$5000(5 \%)$ & 0.012 & 68 & 21 & 11.2 \\
$7500(7.5 \%)$ & 0.011 & 68 & 19 & 12.9 \\
$10,000(10 \%)$ & 0.011 & & \multicolumn{3}{c}{ Contribution } \\
\hline
\end{tabular}

The feed flow was calculated from the percentage (\%, indicated in the bracket) of total freshwater production $\left(100,000 \mathrm{~m}^{3} /\right.$ day $)$.

Table 6 presents a comparison of transmembrane pressure (TMP), flux, and permeate turbidity of previous studies on BW treatment systems with the current study. The table shows that the range of operating TMP was $10-60 \mathrm{KPa}$, and the flux was $960-4000 \mathrm{~L} / \mathrm{m}^{2} / \mathrm{d}$, with an acceptable permeate quality (0.1-1.5 NTU turbidity) in the previous studies. In contrast, the operating pressure and flux in our study were found to be $3.5 \mathrm{kPa}$ and $2000 \mathrm{~L} / \mathrm{m}^{2} / \mathrm{d}$, respectively, with the permeate quality achieving a turbidity of 0.3 NTU. Comparing the results of the current study with previous studies, it is evident that the operating pressure of the current study is approximately 3-30-fold less, with an approximately equivalent quantity and quality of permeate. Therefore, the energy consumption is low, leading to lower operating costs of the system. The manufacturing cost of the clay ceramic filter of the current study was evaluated to be $30 \mathrm{US} \$ / \mathrm{m}^{2}$, whereas those of various commercial polymeric membranes and ceramic symmetric membranes range from 500 to $4000 \mathrm{US} \$ / \mathrm{m}^{2}$ [46]. Furthermore, the lifespan of the clay ceramic filter used in the current study is likely to be longer, as the ceramic membrane offers excellent chemical and fouling resistance. Overall, it can be concluded that the ceramic filtration system appears to be economical and promising for application in BW treatment.

Table 6. Comparison of TMP, flux, and permeate turbidity of different BW treatment systems of previous studies and those of the current study.

\begin{tabular}{|c|c|c|c|c|c|}
\hline Filtration Mode & Materials & TMP (kPa) & Flux $\left(\mathrm{L} / \mathrm{m}^{2} / \mathrm{d}\right)$ & $\begin{array}{c}\text { Permeate } \\
\text { Turbidity (NTU) }\end{array}$ & References \\
\hline Cross-flow MF & Ceramic & 100 & $1200-1600$ & $0.2-1.5$ & [47] \\
\hline Dead-end MF & Polyethylene & $20-60$ & $1000-2000$ & $<0.003$ & [48] \\
\hline Dead-end UF & Polysulfone & 15 & 960 & - & [49] \\
\hline Dead-end UF & Polysulfone & 40 & 1200 & - & [2] \\
\hline Dead-end MF & Ceramic & 30 & 4000 & $<0.1$ & [3] \\
\hline Dead-end UF & $\begin{array}{l}\text { Polyethersulfone } \\
\text { or Polyethylene }\end{array}$ & $10-30$ & $240-1300$ & $<0.6$ & [50] \\
\hline Dead end MF & Polytetrafluoroethylene & 40 & - & $1.6-2.0$ & [7] \\
\hline UF membrnae & Ceramic & 100 & - & 0.14 & [8] \\
\hline Dead-end MF & Clay ceramic & 3.5 & 2000 & $<0.3$ & This study \\
\hline
\end{tabular}

The ceramic filtration system reclaiming BW could significantly reduce the potential environmental impacts associated with land disposal from the discharge of BW from any WTP. This research also revealed that the produced WTBS can successfully be used as an adsorbent for radium removal. 


\section{Conclusions}

The low-cost clay ceramic filter showed high efficiency to separate Fe and Mn hydroxides as well as turbidity from the sand filter BW to make it suitable for recycling. More than $99 \%$ of $\mathrm{Fe}, \mathrm{Mn}$, turbidity, and TSS was removed by simple ceramic filtration. Simultaneously, Fe and Mn oxides in the sand filter BS worked as adsorbents for the effective removal of Ra from groundwater. Over $60 \%$ of Ra removal was achieved by the $\mathrm{BS}$ in $30 \mathrm{~min}$ at neutral $\mathrm{pH}$. The kinetics study revealed that the Ra adsorption mechanisms followed the pseudo-second-order model and were primarily controlled by chemisorption rate-controlling steps, intraparticle diffusion, and external mass transfer processes. Treatment of sand filter backwash water by a low-cost clay ceramic filters and preparation of the BWTS adsorbent for Ra removal would be a sustainable alternative to manage the water treatment BW. A further study including batch adsorption isotherms and the influence of $\mathrm{pH}$ and temperature on Ra removal by the $\mathrm{BS}$ is recommended. Analysis of the performance of the BS using a continuous column study is also necessary to determine the breakthrough curve for Ra removal.

Author Contributions: Conceptualization, M.S.; methodology, M.S. and S.S.A.; validation, M.S., H.H. and M.T.A.; formal analysis, M.S. and H.H.; investigation, M.S., S.S.A., M.T.A. and H.T.; resources, M.S., S.S.A. and M.T.A.; data curation, M.S. and H.H.; writing-original draft preparation, M.S.; writing-review and editing, S.S.A., H.H., M.T.A. and H.T.; visualization, M.S. and H.T.; supervision, M.S.; project administration, M.S.; funding acquisition, M.S. All authors have read and agreed to the published version of the manuscript.

Funding: This research was funded by the Deanship of Scientific Research, Qassim University, grant No. 9905-qec-2019-1-1-Q.

Institutional Review Board Statement: Not applicable.

Informed Consent Statement: Not applicable.

Data Availability Statement: Not applicable.

Acknowledgments: The author(s) gratefully acknowledge Qassim University, represented by the Deanship of Scientific Research, for the financial support for this research under the number (9905qec-2019-1-1-Q) during the academic year 1440 AH/2019 AD. The authors also acknowledge the water treatment plants' management and Water Directorate in Qassim Region of Saudi Arabia for their continuous support in sample collection and laboratory analysis.

Conflicts of Interest: The authors declare no conflict of interest.

\section{References}

1. Walsh, M.E.; Gagnon, G.A.; Alam, Z.; Andrews, R.C. Bio-stability and disinfectant by-product formation in drinking water blended with UF-treated filter backwash water. Water Res. 2008, 42, 2135-2145. [CrossRef]

2. Kim, Y.H.; Eom, J.Y.; Kim, K.Y.; Lee, Y.S.; Kim, H.S.; Hwang, S.J. Applicability study of backwash water treatment using tubular membrane system with dead-end filtration operation mode. Desalination 2010, 261, 104-110. [CrossRef]

3. Weiying, L.; Yuasa, A.; Bingzhi, D.; Naiyun, G. Study on backwash wastewater from rapid sand-filter by monolith ceramic membrane. Desalination 2010, 250, 712-715. [CrossRef]

4. Shafiquzzaman, M.; Al-Mahmud, A.; AlSaleem, S.S.; Haider, H. Application of a Low Cost ceramic filter for Recycling Sand Filter Backwash Water. Water 2018, 10, 150. [CrossRef]

5. Li, S.; Heijman, S.G.J.; Verberk, J.Q.J.C.; Verliefde, A.R.D.; Kemperman, A.J.B.; VanDijk, J.C.; Amya, G. Impact of backwash water composition on ultrafiltration fouling control. J. Membr. Sci. 2009, 344, 17-25. [CrossRef]

6. Ling, Z.L.; Dong, Y.; Zi-Jie, Z.; Ping, G. Application of hybrid coagulation-microfiltration process for treatment of membrane backwash water from water works. Sep. Purif. Technol. 2008, 62, 415-422.

7. Huanga, C.; Lina, J.R.; Leea, W.S.; Pan, J.R.; Zhao, B. Effect of coagulation mechanism on membrane permeability incoagulationassisted microfiltration for spent filter backwash water recycling. Colloids Surf. A Physicochem. Eng. Asp. 2011, 378, 72-78. [CrossRef]

8. Sardari, R.; Osouleddini, N. The dataontheremovalofturbidityand biological agentsinspent filter backwash by bed ceramic in water treatment process. Data Brief 2018, 19, 1794-1798. [CrossRef] [PubMed]

9. Makris, K.C.; O'Connor, G.A. Chapter 28 Beneficial utilization of drinking-water treatment residuals as contaminant-mitigating agents. Develop. Environ. Sci. 2007, 5, 609-635. 
10. Ocinski, D.; Jacukowicz-Sobala, I.; Mazur, P.; Raczyk, J.; Kociołek-Balawejder, Z. Water treatment residuals containing iron and manganese oxides or arsenic removal from wate-Characterization of physicochemical properties and adsorption studies. Chem. Eng. J. 2016, 294, 210-221. [CrossRef]

11. Condomines, M.; Rihs, S.; Lloret, E.; Seidel, J. Determination of the four natural Ra isotopes in thermal waters by gamma-ray spectrometry. Appl. Radiat. Isot. 2010, 68, 384-391. [CrossRef]

12. Al-Masri, M.; Suman, H. NORM waste management in the oil and gas industry: The Syrian experience. J. Radioanal. Nucl. Chem. 2003, 256, 159-162. [CrossRef]

13. Testa, C.; Desideri, D.; Meli, M.; Roselli, C.; Bassignani, A.; Finazzi, P. Determination of uranium, thorium and radium in waters, soils and muds around a uranium mine in decommissioning. Appl. Radiat. Isot. 1994, 45, 394. [CrossRef]

14. Barišić, D.; Lulić, S.; Miletić, P. Radium and uranium in phosphate fertilizers and their impact on the radioactivity of waters. Water Res. 1992, 26, 607-611. [CrossRef]

15. USEPA. Guidelines for Developmental Toxicity Risk Assessment; Risk Assessment Forum, U.S. Environmental Protection Agency: Washington, DC, USA, 1991.

16. USEPA. United States Environmental Protection Agency: Drinking Water Regulations and Health Advisories; EPA 822-B-96-002; Office of Water, USEPA: Washington, DC, USA, 1996.

17. WHO. World Health Organization, Management of Radioactivity in Drinking-Water; WHO: Geneva, Switzerland, 2018; ISBN 78-92-4151374-6.

18. Alkhomashi, N.; Al-Hamarneh, I.F.; Almasoud, F. Determination of natural radioactivity in irrigation water of drilled wells in northwestern Saudi Arabia. Chemosphere 2016, 144, 1928-1936. [CrossRef]

19. Almasoud, F.; Ababneh, Z.Q.; Alanazi, Y.J.; Khandaker, M.U.; Sayyed, M. Assessment of radioactivity contents in bedrock groundwater samples from the northern region of Saudi Arabia. Chemosphere 2020, 242, 125181. [CrossRef]

20. Kumar, A.; Karpe, R.; Rout, S.; Gautam, Y.P.; Mishra, M.; Ravi, P.; Tripathi, R. Activity ratios of 234U/ 238U and 226Ra/ 228Ra for transport mechanisms of elevated uranium in alluvial aquifers of groundwater in south-western (SW) Punjab, India. J. Environ. Radioact. 2016, 151, 311-320. [CrossRef]

21. Turhan, S.; Özçıtak, E.; Ta skın, H.; Varinlioglu, A. Determination of natural radioactivity by gross alpha and beta measurements in ground water samples. Water Res. 2013, 47, 3103-3108. [CrossRef] [PubMed]

22. Al-Zubari, W. Sustainable Water Consumption in Arab Countries. In Arab Environment: Sustainable Consumption. Annual Report of Arab Forum for Environment and Development, 2015; Abdel Gelil, I., Saab, N., Eds.; Technical Publications: Beirut, Lebanon, 2015; pp. 108-133.

23. Haider, H.; Al-Salamah, I.S.; Ghumman, A.R. Development of Groundwater Quality Index using Fuzzy-based Multicriteria Analysis for Buraydah, Qassim, Saudi Arabia. Arab. J. Sci. Eng. 2017, 49, 4033-4051. [CrossRef]

24. Al-Hamarneh, I.F.; Alkhomashi, N.; Almasoud, F. Study on the radioactivity and soil-to-plant transfer factor of 226Ra, 234U and $238 \mathrm{U}$ radionuclides in irrigated farms from the northwestern Saudi Arabia. J. Environ. Radioact. 2016, 160, 1-7. [CrossRef]

25. Khedr, M.G. Radioactive contamination of groundwater, special aspects and advantages of removal by reverse osmosis and nanofiltration. Desalination 2013, 321, 47-54. [CrossRef]

26. Baeza, A.; Salas, A.; Guill_en, J.; Mu noz-Serrano, A.; Ontalba-Salamanca, M.A.; Jim_enez-Ramos, M.C. Removal naturally occurring radionuclides from drinking water using a filter specifically designed for Drinking Water Treatment Plants. Chemosphere 2017, 167, 107-113. [CrossRef] [PubMed]

27. Clifford, D.A.; Zhang, Z. Modifying ion exchange for combined removal of uranium and radium. J. Am. Water Works Assoc. 1994, 86, 214-227. [CrossRef]

28. Samolej, K.; Chalupnik, S. Investigations on the application of different synthetic zeolites for radium removal from water. $J$. Environ. Radioact. 2021, 229-230, 106529. [CrossRef] [PubMed]

29. Erenturk, S.; Kaygun, A.K. Removal of 226Ra from aqueous media and its thermodynamics and kinetics. J. Radioanal. Nucl. Chem. 2017, 311, 1227-1233. [CrossRef]

30. Chalupnik, S.; Franus, W.; Wysocka, M.; Gzyl, G. Application of zeolites for radium removal from mine water. Environ. Sci. Pollut. Res. 2013, 20, 7900-7906. [CrossRef] [PubMed]

31. Nagar, M.S.; Abdou, A.A.; Abdel, R.; Ghazala, S. Removal of Radium from Uranium Effluent by Manganese Oxide Coated Modified Bentonite (Mn-NaB) Mediterranean. J. Chem. 2018, 7, 105-114.

32. Chen, M.A.; Kocar, B.D. Radium Sorption to Iron (Hydr) oxides, Pyrite, and Montmorillonite: Implications for Mobility. Environ. Sci. Technol. 2018, 52, 4023-4030. [CrossRef]

33. Wołowiec, M.; Komorowska-Kaufman, M.; Pruss, A.; Rzepa, G.; Bajda, T. Removal of Heavy Metals and Metalloids from Water Using Drinking Water Treatment Residuals as Adsorbents: A Review. Minerals 2019, 9, 487. [CrossRef]

34. Shen, C.; Zhao, Y.; Li, W.; Yang, Y.; Liu, R.; Morgen, D. Global profile of heavy metals and semimetals adsorption using drinking water treatment residual. Chem. Eng. J. 2019, 372, 1019-1027. [CrossRef]

35. Shafiquzzaman, M.; Hasan, M.M.; Nakajima, J.; Mishima, I. Development of a simple and effective arsenic removal filter based on ceramic filtration. J. Water Environ. Technol. 2011, 9, 333-347. [CrossRef]

36. Ho, Y.S.; McKay, G. Pseudo-second order model for sorption processes. Process. Biochem. 1999, 34, 451-465. [CrossRef]

37. Plazinski, W.; Dziuba, J.; Rudzinski, W. Modelling of sorption kinetics: The pseudo-second order equation and the sorbate intraparticle diffusivity. Adsorption 2013, 19, 1055-1064. [CrossRef] 
38. Liu, W.; Zhang, J.; Zhang, C.; Wang, Y.; Li, Y. Adsorptive removal of Cr (VI) by Fe-modified activated carbon prepared from Trapa natans husk. Chem. Eng. J. 2010, 162, 677-684. [CrossRef]

39. APHA. Standard Methods for the Examination of Water and Wastewater; American Public Health Association (APHA): Washington, DC, USA, 2005.

40. Sethi, S.; Wiesner, M.R. Simulated cost comparisons of hollow-fiber and integrated nanofiltration configurations. Water Res. 2000, 34, 2589-2597. [CrossRef]

41. Li, J.H.; Zheng, L.R.; Wang, S.L.; Wu, Z.; Wu, W.; Niazi, N.; Shaheen, S.M.; Rinklebe, J.; Bolan, N.; Ok, Y.S.; et al. Sorption mechanisms of lead on silicon-rich biochar in aqueous solution: Spectroscopic investigation. Sci. Total Environ. 2019, 672, 572-582. [CrossRef] [PubMed]

42. Almasoud, F.I.; Al-Farraj, A.S.; Al-Wabel, M.I.; Usman, A.R.A.; Alanazi, Y.J.; Ababneh, Z.Q. The Potential Use of Zeolite, Montmorillonite, and Biochar for the Removal of Radium-226 from Aqueous Solutions and Contaminated Groundwater. Processes 2020, 8, 1537. [CrossRef]

43. World Health Organization (WHO). Guidelines for Drinking Water Quality, 2nd ed.; World Health Organization: Geneva, Switzerland, 2004.

44. Lopez, M.M.C.; Perez, M.C.C.; Garcia, M.S.D.; Vilarino, J.M.L.; Rodriguez, M.V.G.; Losada, L.F.B. Preparation, evaluation and characterization of quercetin-molecularly imprinted polymer for preconcentration and clean-up of catechins. Anal. Chim. Acta 2012, 721, 68-78. [CrossRef]

45. World Health Organization (WHO). Guidelines for the Safe Use of Wastewater, Excreta and Greywater, Volume 4: Excreta and Greywater Use in Agriculture; WHO: Geneva, Switzerland, 2006.

46. Nandi, B.K.; Uppaluri, R.; Purkait, M.K. Treatment of Oily Waste Water Using Low-Cost Ceramic Membrane: Flux Decline Mechanism and Economic Feasibility. Sep. Sci. Technol. 2009, 44, 2840-2869. [CrossRef]

47. Vigneswaran, S.; Boonthanon, S.; Prasanthia, H. Filter backwash water recycling using crossflow microfiltration. Desalination 1996, 106, 31-38. [CrossRef]

48. Willemse, R.J.N.; Brekvoort, Y. Full-scale recycling of backwash water from sand filters using dead-end membrane Filtration. Water Res. 1999, 33, 3379-3385. [CrossRef]

49. Reissmann, F.G.; Uhl, W. Ultrafiltration for the reuse of spent filter backwash water from drinking water treatment. Desalination 2006, 198, 225-235. [CrossRef]

50. Ćurko, J.; Mijatović, I.; Rumora, D.; Crnek, V.; Matošić, M.; Nežić, M. Treatment of spent filter backwash water from drinking water treatment with immersed ultrafiltration membranes. Desalination Water Treat. 2013, 51, 4901-4906. [CrossRef] 